\title{
Banquets, Politics, and Representation in Nineteenth-Century Colombia
}

\author{
Lee Skinner/ Tulane University
}

Representations of food and its consumption often function to mobilize particular ideas around identity, social class, and political ideologies. In nineteenth-century Colombia, as in Latin America generally, people debated, even battled, over political ideologies. Such debates often became deeply personal in many senses, touching on regional, ethnic, and national identities and lifestyles. It is not surprising, then, that meals became a vehicle for the transmission of ideas and perspectives on the future of Colombia, international relations, modernization, and more. The preparation and consumption of food in public spaces in nineteenth century Colombia constitutes a topic both common and unspoken. As a fundamental necessity, food was overwhelmingly important; as a daily practice, it was so natural as to frequently go unremarked. As Priscilla Ferguson comments, "Food surely can be construed as a 'total social phenomenon,' as Marcel Mauss defined it - that is, as a set of experiences and practices so pervasive that we could not imagine our worlds without them. From the kitchen to the dining table and beyond, the talk generated by food draws our attention because of its connection to our social selves" (Ferguson 2014, prologue). An analysis of the representations of scenes of eating sheds light on the ways in which writers deployed seemingly commonplace activities such as hosting a banquet or dining at a hotel in order to advance specific ideas and viewpoints about such topics. This essay teases out some of the cultural codes and modes of understanding embedded in representations by nineteenth century Colombians of their relationships with the consumption of food in public spaces such as restaurants and public banquets in order to destabilize those apparently seamless representations - to pick apart the seams, as it were, and to understand the ways in which normalized and supposedly natural behaviors may be depicted to connect to more obviously constructed ideological and social ideas.

While economic conditions in Colombia in the nineteenth century were not propitious for the rapid growth of a substantial middle class such as occurred in countries elsewhere on the continent such as Mexico or Argentina, nonetheless steady economic expansion meant that increasingly throughout the century, more Colombians had access to elements of a lifestyle typically associated with the landed aristocracy and the small elite that dominated political and cultural life. The upper class exercised a cultural influence disproportionate to its size. Members of the elite, especially in Bogotá, emulated the customs and consumption practices of the elites of other countries, about which Colombians learned from their own travels to Europe and North America and from imported publications. Colombian magazines and newspapers, too, published news and information about political, economic, social and cultural events in Europe and the United States, enabling a larger group of readers to partake, albeit vicariously, in the cultural practices of those places. Nineteenth century Latin Americans frequently looked to Europe- especially to France and England - and to the United States as countries that incarnated the virtues and benefits of modernity and progress, conditions to which these Latin Americans aspired and which they strove to create in their own countries. Foreign merchants living in Colombia, especially in Bogotá and Cartagena, worked to create a market for imported goods by associating their literal consumption with an elevated cultural status and with the refinement and elegance thought to be the province of Europe and North America. As Arnold Bauer puts it, "these new clusters of people that later will be called [...] a middle class sought through consumptions and behavior to distinguish themselves from the unwashed rural mass while groping for marriage and membership in the still essentially white elite" (Bauer 2001, 133). The elites thus maintained their own status by participating in rituals of consumption involving imported goods and ideas, and the aspiring middle class worked to gain a foothold on the social ladder by likewise participating in such activities as purchasing imported goods, dining in hotels, and serving French and English foods in their homes. Just as these people bought British textiles, German pianos, and French hats to display their sophistication, so too they drank English tea, French wines and German beers, or ate sandwiches, enjoyed "onces" (from the English elevenses) and spread French preserves on their bread.

Although the members of the upper classes shared a privileged lifestyle, political divisions cleaved the nation, and the elites, as Liberals and Conservatives battled, often literally, for control. They struggled over how to define their nation, the role of religion and the Church in public life, the economy and trade, and racial and ethnic identities, among many other differences. Cristina Rojas explains one of the fundamental difficulties confronting newly-minted Colombians after the Wars of Independence: "On the one hand, the process of unification of the republic sought a sense of shared identity for its fellow citizens. But on the other hand, basing hegemony on the civilizing desire invited a distancing between the creole elite and the "ignorant masses" (Rojas 2001). How to 
navigate the complex relationship between elites and masses preoccupied those on both sides of the political divide. They used open violence, political confrontations, and also social interactions and print media to enact their disputes, and contended with each other over the occupation and use of public and private spaces for political and other purposes. In this environment, food and its public consumption also had a political aspect and the realms of the social and the political intersected and influenced one another. Here Pilar González Bernardo de Quirós's understanding of sociability as addressing both "prácticas de interacción más o menos formalizadas" and a way to "pensar la sociedad como producto del vínculo social" (González Bernardo de Quirós 2015, 2) is helpful in drawing critical attention both to the formal and informal networks of organizations, fraternal associations, political societies, workers' groups and clubs and the concept that social connections such as shared meals produce society. As she explains:

Lo político como modalidades de existencia de la vida en común implica y está configurado por las representaciones del vínculo social y [...] para acceder a ello debemos considerar tanto los conceptos cada una de las formaciones sociales producen sobre el vínculo social como las prácticas de interacción social que se inspiran y son percibidas a través del prisma de esas representaciones sociales" (González Bernardo de Quirós 2015, 2).

Not only did people use food to signal their wealth, power and social class, but representations of meals in the popular press served to communicate the diners' - and sometimes the journals' - political affiliations, and to provide commentary on political events. Banquets were frequently celebrated and were a source of double signification. A banquet might honor a particular guest, organization, or even an entire nation in the form of a foreign delegation; rally supporters to a political cause; or mark the celebration of a historical event. Such banquets were reported on in local or national newspapers, creating a second level of meaning as a wider group than had attended the banquet itself actually read about the banquet and what it signified. These accounts of banquets in periodicals served an important purpose. Rojas points out that "wealth was not the source for the exercise of power in nineteenth-century Colombia, but rather the 'surplus of vision' of the literati, which resulted from their being the owners of civilization in the middle of an illiterate society. Grammar conferred on the literati the capacity not only to write the rules of grammar, political economy, and constitutional law, but also to impose their vision from the highest levels of political power" (Rojas 2002, 55). The ability to promote particular versions of events and political debates through the press reinforced the upper class's hold on power and also gave Liberals and Conservatives another venue in which to enact their differences and to try to define public and private spaces and political movements in their own ways. As banquets were memorialized in print, journalists added commentaries about the meaning and importance of the events described, interpreting the ritualized meal for their readers.

Banquets themselves were highly regulated events, as were all social activities and interactions. Manuel Antonio Carreño's Manual de urbanidad, first published in 1853, became a bestseller throughout Spanish America following the 1854 Appleton edition and 1857 Caracas second edition, and remains in print to this day. Carreño dictated to the elites and, perhaps more importantly, to those who aspired to be or be seen as elite, every aspect of their private and public lives, often in ways that blurred the lines between the public and the private spheres. He asserted in his introduction that peace, order and happiness among human beings depended on their ability to practice moral laws and went on to define morality as intimately connected to urbanity and virtue. Natalie López indicates that the Manual

establece [...] las pautas ideales de un nuevo orden que partía por elreordenamiento del cuerpo, el orden mínimo, es decir, el orden gestual que, a su vez, permitiría el orden de las jerarquías. En países marcados por la inestabilidad política surge, pues, la urgencia del dictamen de códigos normativos que devolvieran a cada uno el sitio que las élites hegemónicas habían dispuesto para cada cual. (López 2017, 649)

These normative codes not only formalized social and political hierarchies among groups of people, but determined how individuals interacted with one another and imposed controls and laws on the spaces and events where those interactions took place.

In March of 1850 , several newspapers reported on a banquet in Popayán held by Julio Arboleda, whose career and many activities are neatly summed up as "hacendado, esclavista, abogado, orador, poeta, militar, periodista, político, diplomático, parlamentario, académico, dramaturgo y estadista colombiano" (Enciclopedia Banrepcultural, n.d.). Arboleda led the Conservative opposition to the government of José Hilario López, president of Nueva Granada from 1849 to 1854. López's government proposed the absolute liberty of all slaves, not just those born after 1821, although slavery was not abolished until January 1, 1852 (Tovar Pinzón 1994). On the other hand, Arboleda was an active slave-trader, exporting and selling slaves between 1844 and 1847 along with other plantation owners (Tovar Pinzón 1994). This political conflict was the backdrop for the banquet hosted by Arboleda, on which the journal La Civilización reported in its March 14, 1850 issue in a piece titled "Indignación pública." La Civilización was a Conservative journal founded and edited by Mariano Ospina Rodríguez and José Eusebio Caro in August 1849 in Bogotá (Cubillos Vergara 2012,6). This came only a month after Ospina Rodríguez and Caro purchased 
another newspaper, El Día, and made it an opposition paper to López's government (Vasco Bustos 2011, 71). El Día also reported, much more extensively, on Arboleda's banquet, as we shall see. The account in La Civilización praises the banquet and, more importantly, the speeches given during it:

Tuvo lugar en la casa del Sr. Julio Arboleda un banquete republicano, que por el concurso y demás circunstancias de él, ha sido el más espléndido y lúcido que se ha visto en Popayán desde que hay memoria de banquetes. Se pronunciaron muy bellos y elocuentes discursos, alusivos a la angustiosa y difícil situación a que la República es ciegamente conducida por las violentas pasiones de los hombres, que adueñados del poder, han creído que pueden obrar en el país como en una ciudad enemiga tomada por asalto, y entregada a saco. Entre otros discursos se habla como de una obra magnífica el pronunciado por el Sr. Arboleda. Sentimos vivamente que estos arranques poderosos del patriotismo y del talento no se hayan circulado por la imprenta. Su publicación nos habría hecho participar de lo mejor y más estimable del gran banquete a todos los que participamos de las mismas ideas, que nos sentimos animados de los mismos sentimientos. [...] Durante el banquete fueron aprehendidos dos hombres rojos destinados a turbarlo; y uno de ellos fue desarmado al tiempo de hacer fuego al general Mosquera, con una de dos pistolas que llevaba cargadas cada una con una bola y 23 postas; y este mismo, llamado Rafael Caldas, dijo: que había recibido orden para enviar al otro mundo el alma del señor Julio Arboleda. ¡Testimonio precioso de la fraternal democracia roja! (La Civilización 1850)

This simultaneously detailed yet sparse description of the banquet serves multiple purposes. Rather than giving details about the menu of this banquet, the author of the report uses the occasion to focus on the political nature, although not the exact content, of the speeches given during the banquet. While assuring his readers that the guests constituted an illustrious group, no attendees other than Arboleda, the would-be assassin Caldas, and Caldas's victim Mosquera are named. Clearly the intention of the article is not to inform La Civilización's audience of the banquet qua meal, but to use the description of the banquet to further a political agenda. The banquet itself also, of course, constitutes an occasion for political discourse; it was clearly organized by Arboleda to provide a venue for anti-government Conservative speakers. La Civilización mobilizes these different levels in order to communicate forcefully its message that Conservatives are true patriots and adhere to the rule of law. Given that, as Carreño avers, law, virtue and urbanity are so intertwined as to be indistinguishable, the efforts of the "hombres rojos" to disrupt the banquet violate social, political and moral norms. Their assassination attempt is all the more egregious because it interrupts the normal order of the banquet. Following the social laws about banquets inserts the host and his guests into urbanity and civilization; they also actively reproduce the codes of civilized behavior and foster those norms by following them publicly and by the publication of the account in La Civilización and, later, El Día. Beatriz González Stephan argues that the Manual "impone el discurso de la prohibición" (González Stephan 1995, 444). The civilized guests and their host are allowed; the uninvited intruders are prohibited, both from the banquet and from the figurative space of civilization.

The journalist did not attend the banquet and listen to the speeches first hand, which we know because he writes about Arboleda's speech in the third person ("se habla como de una obra magnífica el pronunciado por el Sr. Arboleda"). This strategy actually intensifies the impact of Arboleda's speech, as the implication is that many people - all those at the banquet - were favorably impressed by it, not only the journalist himself. The positive evaluation of the speech is more authoritative as it is shared by many rather than being the opinion of one man. At the same time that the writer laments the lack of circulation of the speeches, he creates a virtual community of like-minded citizens by projecting their potential (probable) reception by referencing "todos los que participamos de las mismas ideas, que nos sentimos animados de los mismos sentimientos." While the first iterations of verbs in nosotros could be explained as the authorial "we" standing in for a singular "yo/I", here it is clear that Arboleda's political sympathizers are multiple, and that they are bound together in an affective political community. In that community's view, their nation is under attack both figurative and literal. The current wielders of power treat the republic as if it were a conquered city, in the writer's vivid metaphor. Liberals and Conservatives are bitter enemies in this construction. This leads in to the news that, in fact, two armed men were detained; the banquet, a space where political views were openly voiced, is a battleground, and the primary target was Arboleda himself, whose speech was the only one singled out in the article as especially noteworthy. Only when the two attackers appear on the scene and on the page does the writer specify that the conflict is between Liberals (the rojos) and Conservatives, although given the overt political stance of La Civilización and Arboleda's well-known political affiliation readers would have quickly made the connection. The description of the banquet transmits on multiple levels the message that Conservatives are peaceful guardians of the integrity of democracy in Colombia; that democratic institutions in Colombia are under attack; and that Liberals are opposed to the open expression of political ideas. Cristina Rojas proposes that violence can be conceived of having three dimensions: representation, manifestation, and resolution. By representation, she means "the act of fixing identities" and further glosses that "to name an action rational, to designate an actor as legitimate, to describe a process as efficient is to condemn another as irrational, illegitimate, or backward. The moment of representation is crucial to understand the violence 
inherent in processes of identity formation" (Rojas 2001, 21). By emphasizing the interruption of the orderly progress of the banquet by the Liberal attackers, the writer, in Rojas's terms, himself inflicts the violence of representation on them, fixing their identity as "irrational" and "illegitimate."

While La Civilización's account covered the banquet in general terms, including the speeches, El Día's report on the banquet, written by José María Torres Caicedo, includes far more detail about the preparation and consumption of the meal itself, as well as about some of the participants in the event, perhaps because the account was written several weeks after La Civilización published its report. El Día devoted substantial parts of several issues to the founding of the Sociedad Popular de Republicanos de Popayán, whose inaugural event was the banquet in Arboleda's house. As Gilberto Loaiza Cano explains, "En Popayán, la Sociedad Popular de Republicanos fue obra de los terratenientes conservadores que no estaban interesados en la abolición de la esclavitud, encabezados por Julio Arboleda (1817-1862), que luego fue encarcelado y se exilió en Perú, responsable de organizar una coalicion de militares y políticos conservadores contra el régimen liberal de José Hilario López" (Loaiza Cano 2011, 231). The liberals had systematically worked to establish functional political networks throughout the country connecting the elites and the artisan classes, often fostering and promoting those relationships through Sociedades democráticas (Loaiza Cano 2011, 78-79). The creation of Sociedades populares and other Catholic-connected social organizations was one of the responses of the Conservatives and the Church to those Liberal efforts (Uribe-Urán 2003, 104-105). Arboleda had long been involved in the creation and promotion of such societies, having been a key mover in the foundation of the Sociedad Patriótica de los Amigos del Orden in the 1830s. Of that society, Willian Alfredo Chapman Quevedo explains, "el objetivo fue canalizar el proceso de politicización de los nuevos ciudadanos y mediar entre éstos y el Estado, lo pretendido era que la asociación se convirtiera en parte de la vida del individuo [...]. Así, a través de sus estatuos la Sociedad Patriótica cruzaba las fronteras de lo privado y se ubicaba en el terreno de lo público" (Chapman Quevedo 2013). These Conservative-affiliated societies "lograron situarse en los principales núcleos urbanos, donde les disputaron la presencia pública a las Sociedades democráticas hasta el punto de provocar un clima cotidiano de hostilidad en las calles entre quienes se identificaban como democráticos y quienes se apodaban conserveros" (Loaiza Cano 2011, 229). The violence that took place in Popayán at Arboleda's house, then, was not unexpected; nor was the elision of the public and the private. Moreover, as we shall see shortly, the struggle for domination of public spaces, be they literal or figurative, also figured importantly in this case.

El Día's version foregrounds the preparations for the meal and its physical location including the positions of guests and tables and details how events unfolded during the banquets and the speeches given at it. Thus Torres Caicedo specifies that the day of the banquet:

[L]as señoras de la ciudad estaban preparando el gran banquete en el patio y corredores bajos de la casa de la señora Sofía Mosquera, esposa del señor Julio Arboleda. Este banquete, al estilo inglés, constaba de una serie de mesas alrededor de los cuatro corredores y en el espacioso patio en forma de cruz griega. Más de quinientos cubiertos se ordenaban sobre blancos manteles, que expresaban la pureza de los sentimientos conservadores. Veíanse de todas las calles de la ciudad un número crecido de sirvientes de ambos sexos conduciendo al lugar del banquete los manjares más exquisitos, las carnes y pavos lujosamente preparados, y cuanto se necesita para cubrir entre las naciones cultas una mesa, a la cual se llama al pueblo ilustrado. [...] Los postres y las frutas ocupaban capaciosas salones de la casa [...]. Los corredores altos estaban cubiertos del bello sexo, hermoseando así el sagrado recinto en donde se estrecharían los corazones republicanos. (Torres Caicedo 1850)

This description brings to the reader's attention the active involvement of elite women - and their servants - in the preparations for the banquet. When the hundreds of guests arrive, the women wait on the sides of the four hallways; only "las mujeres del pueblo" join the men to eat, but female presence is notable here while it was omitted in La Civilización's rendering of the event. El Día stresses the orderly, peaceful nature of the banquet: "No se oía una sola palabra antisocial o descomedida. El contento, el humor general y el orden, eran generales en todos los ángulos del edificio." In this, the guests obeyed Carreño's stricture that "en la mesa [del banquete] debe sostenerse siempre una conversación ligera y agradable, que mantenga constantemente viva la animación y alegría de la concurrencia, y que esté exenta de toda palabra o alusión que en alguna manera sea impropia de las circunstancias" (Carreño 1853, 236). Moreover, social norms dictated that the presence of upper-class women required all others present to follow more stringent codes of deportment, such as refraining from vulgar or insulting language or violence. Women, in short, were seen to be civilizing influences, and elite men and those who aspired to the elites were supposed to behave accordingly or run the risk of being considered barbaric; indeed, as González Stephan notes, Carreño's manual has at its core "la domesticación de la sensibilidad 'bárbara" (González Stephan 1994, 434-5). Torres Caicedo's emphasis on the presence and participation of numerous women, coupled with his references to the tranquil, joyous atmosphere and polite behavior of the guests ("cada cual se esforzaba en servir al vecino," for example), create a picture of an eminently orderly event. This makes the disruption of that event by the violent, loud, rowdy Liberals even more striking. 
The representation of the banquet plays on the uneasy intersection and fault lines between the private and public spheres. The home is considered a private, even intimate space, reserved for family and those close to them. Throughout the nineteenth century the division between the two spaces became more and more sharply drawn, as the ideology of the angel in the house increasingly dominated middle- and upper-class discourse about the home and gender roles in the family and in society. According to that ideology, women were naturally suited to the home, which was meant to be a refuge for their male relatives returning from the hurlyburly of the public sphere. Politics and paid work took place in the public realm and were the province of men. In El Día, Arboleda's banquet crosses, re-crosses, and re-draws the boundaries between public and private. Torres Caicedo foregrounds the involvement of women, writing that the banquet takes place "en la casa de la señora Sofía Mosquera," Arboleda's wife. This phrasing makes it crystal clear that Sofía Mosquera controls the space of the house, and she and other elite women of Popayán are responsible for organizing the meal itself and for instructing their domestic servants to obtain and cook the food. The memoirist José María Cordovez Moure emphasized the in-house preparation of food for parties and banquets before 1860, praising "las exquisitas colaciones y dulces hechos en la casa, [...] pues se consideraba como una profanación del hogar hacer uso de alimentos preparados fuera de él" (De la vida de antaño 1936, 22-23). Finally, the women remain in the halls to watch and listen to the oratory. These details highlight the domestic nature of the event, at the same time that references to politics point toward the banquet's role in the public sphere. This is notable in, for example, the description of the "blancos manteles, que expresaban la pureza de los sentimientos conservadores." The fact that the women are permitted to stay in the courtyard and witness the political speeches signals the thoroughness with which the boundaries between public and private are erased in this case. Politics are, literally, brought home as participants toast to "el orden público," "los defensores del Gobierno en los años de 40 y 41 ," referring to the civil war that raged then, and "la Sociedad Popular de republicanos" before Arboleda's interrupted speech, which he begins during the dessert course.

As in La Civilización's rendition of the banquet and its aftermath, Torres Caicedo employs vocabulary and structures that impart the important message that the Conservatives are inherently peaceful and that the Liberals are aggressors in the conflict, repeating the violent inscription of them as barbaric that was initiated in La Civilización. The positioning of the banquet in Arboleda's home highlights the invasion of the two men who threaten Arboleda with violence. The potential assassin is called an "intruso" and, while he and his companion are armed and intent on harming Arboleda and mean to "perturbar el orden en el banquete popular," they are "espelidos a la calle sin lesión alguna," bespeaking the good intentions of the guests who neutralize them. While the speeches continue within the house, the liberals outside "se dirigieron frenéticos hasta las puertas de la casa; pero no se atrevieron a penetrar, convencidos de que la lucha les era desventajosa. Por muy bien armados que hubiesen penetrado, a los conservadores les sobraban armas con los cuchillos de la mesa para despedazarlos." Even the eating implements become instruments of violence due to the aggression of the Liberals against what should be the refuge of the private home and the well-regulated, urbane activity of the banquet. Torres Caicedo emphasizes the explosion of violence and the loss of civil political discourse caused by the Liberals' attack. Rojas states, "The desire to eliminate the Liberal Party was accompanied by the logic of equivalence, where all positive determinations belonged to the Conservative Party and everything in the Liberal Party was equated with violence" (Rojas 2001, 40-41). Yet Torres Caicedo's account also, if inadvertently, calls attention to the role played by the Conservatives in exacerbating these political tensions and in destroying the supposed peace of the private home. The Conservatives are responsible for bringing politics into the home by staging the banquet and inviting (or requiring?) the cooperation of the women and servants of Popayán's elite families, and they are prepared to take up arms against potential invaders by snatching the knives off the tables. More, they are prepared not just for self-defense but for active assault, as they have ample weaponry with which to "despedazar" the attackers.

It was typical that banquets at mid-century, especially in regional cities, were held in private homes, as restaurants catering to the elite were not widespread at that point. Writing of Bogotans making the trek to smaller towns and cities, Cordovez Moure notes, "antaño era casi desconocido en nuestras pequeñas poblaciones el servicio de fondas, hoteles o cosa parecida" (Reminiscencias de Santa Fé y Bogotá 1899, 140). Even a well-appointed restaurant in a larger city, had such facilities existed at that time, would not have been able to accommodate the hundreds of guests who attended Arboleda's festivities. Other examples of banquets at mid-century, less politically tense than the meeting of the Sociedad Popular de Republicanos, were also celebrated in private homes, and thanks to Jerónimo Argáez's 1878 tome El Estuche, conocimientos útiles aplicados a la vida práctica o sean 8000 recetas y hechos diversos, compilados por John Truth, we can reconstruct what such dinners entailed or, at least, what was expected of their hosts. Argáez gives specific instructions for banquets in private homes, starting with the number of waiters needed (six, for a dinner seating twelve guests), and laid out the order of the numerous courses, starting with raw oysters; soup; an entremes of pastelillos; fish; a cold entree followed by steak; vegetables; candies; salad and cheese (Argáez 1878, 19-20). After the above courses had been consumed, the waiters cleared the table completely and re-set it for the dessert courses, which began with an ice, followed by fruit compote and cake, then fresh pineapple with sugar, fresh strawberries with sugar, and other fruits. At last the guests were served coffee and liqueurs (Argáez 1878, 
21). Each one of these courses was to be paired with wine, which Argáez also specified.

The September 8, 1852 issue of El Pasatiempo reproduced the report by Rafael Malo in El Correo de Caracas of one of these banquets held in Caracas. The Colombian diplomat José María Rojas Garrido threw the dinner in honor of the independence of Nueva Granada and invited 15 men to his home, including Malo ("nos reunimos en la casa de habitación del espresado Sr. Dr. Rojas, por invitación suya"). Like Arboleda's much larger dinner, Rojas's banquet blends the public sphere of politics with the private sphere of domestic life. Here, given the small number of guests, Rojas deploys the invitation to his home to signal exclusivity and an access to intimacy awarded to a privileged few, thus presenting the entry to his residence as a particular way to honor his invitees. Jacques Derrida theorizes the uneasy relationship between host and guest in On Hospitality, claiming that hospitality is always already conflicted. Hospitality may be defined as the welcome without limits of the guest; but it may also be regimented by law, since it also may have the purpose of someone to take a stranger as hostage in a stranger's home, and hospitality retains the vestiges of these associations: "We will always be threatened by this dilemma between, on the one hand, unconditional hospitality that dispenses with law, duty, or even politics, and, on the other, hospitality circumscribed by law and duty" (Derrida 2000, 135). Now, says Derrida, the host actually becomes a hostage, because the guest enters "to lay down the law and liberate the people or the nation by coming from outside, by entering into the nation or the house, into the home that lets him enter after having appealed to him. It's as if $[\ldots]$ the stranger could save the master and liberate the power of his host" (Derrida 123). In this way the master, the host, becomes the hostage, and the guest (the invited hostage) becomes the host of the host. "These substitutions make everyone into everyone else's hostage" (Derrida 125). This dynamic is writ large in representations of banquets and the interactions of the host with his guests.

Malo's rendition underscores the melding of personal favors with political purposes: "Llegada la hora, el Sr. Dr. Rojas, con la acostumbrada amabilidad y finos modales que le caracterizan y le captivan las simpatías de cuantos tienen el honor de tratarle familiarmente, nos condujo a la mesa [...]. El buen gusto del Sr. Dr. Rojas no dejó nada que desear en este espléndido banquete, servido con la mayor abundancia, variedad y elegancia que puede alcanzarse en nuestro país." Malo emphasizes his close connection with Rojas, describing elements of his personal style such as his "finos modales" that are bestowed on those who "tienen el honor de tratarle familiarmente," a group among whose number Malo clearly includes himself with his use of "nosotros." As Malo writes, representatives of each country praised one another in toasts and vowed international cooperation and partnership; the banquet's stated goal is to foster collaborations and ties between the two countries, returning us to Derrida's critique of hospitality as coetanous with diplomacy but also hostage-taking. Toasts, Manuel Antonio Carreño instructs his readers, may only be given in certain situations:

Solo en las reuniones numerosas, y en todas aquellas que tienen algún carácter público, oficial o diplomático, están recibidos los discursos llamados brindis. Las personas que han de pronunciarlos, están naturalmente llamadas a ello por su posición particular respecto del objeto del convite, por su categoría o su representación social, y a veces expresamente designadas con su debido consentimiento (Carreño 1853, 239).

The act of toasting creates and reinforces social ties, sociability, as the participants recognize one another as partaking in the shared experience and as understanding the social codes that regulate the toasts.

By writing and publishing this account of the banquet, Malo also allows his readers to enter the intimate, private space and experience of the banquet as described in the pages of El Correo de Caracas and then El Pasatiempo. He deliberately employs the publication of this information to promote the banquet's goal - the shared history and future of the two nations - beyond the limited guest list itself: "Deseoso de dar la mayor publicidad a los interesantes incidentes que dejo referidos, he querido valerme de la circulación del periódico que ustedes redactan," he concludes his account. Both $E l$ Correo de Caracas and El Pasatiempo actively engage in the consolidation of national ties by acceding to Malo's request, and to the flattery about their circulation implied when he states that publication in these two newspapers will result in "la mayor publicidad." The banquet in and of itself is not sufficient to achieve its avowed objective; dissemination of the news of the banquet, and most importantly, of the interpretation Malo gives to the event as one of true international cooperation and friendship, is a vital component of this process.

Nonetheless, such banquets did not always achieve their goal. On February 15, 1854 El Pasatiempo reported on a banquet that had been recently hosted by President José María Obando: "El sábado último ha dado el Presidente de la República [Obando] un banquete oficial, que tiene para nosotros mucha significación." The newspaper lists some of the guests, a mingling of Liberals and Conservatives, and even of different factions within those parties, including Mariano Ospina Rodríguez, Manuel Murillo Toro, Julio Arboleda and José de Obaldía, among others. The banquet thus brings together representatives of the uprising of pro-slavery landowners with the Liberals who had suppressed their rebellion, signifying the peaceful co-existence and co-governance that has been achieved: "Ya los gobernantes y los revolucionarios proscritos, los enemigos más enconados, los adversarios menos conciliables, se han encontrado reunidos en un 
banquete." El Pasatiempo inserts editorial comments and judgments in recounting the event and emphasizes the ways in which the physical gathering of these erstwhile opponents represents their political cooperation and hence, the success of the democratic process. The act of physically and metaphorically uniting the literally warring parties is more noteworthy than the food consumed and bespeaks "la grandeza de la República" as well as, crucially, serving as "una especie de prueba tácita y espléndida de la noble generosidad del partido liberal" (352). Ostensibly meant to foster political unification and the equality of the two parties, El Pasatiempo's editorial comments instead establish a hierarchy that subordinates the Conservatives to the Liberals and undermines the newspaper's own efforts to create an image of political harmony; this is another example of the violence of representation described by Cristina Rojas. Ironically, Obando would be overthrown by a liberal-conservative coalition only two months later, on April 17, 1854.

At mid-century, the market for luxury imported goods, including food and drink, remained small, as did the desire to emulate the modes of those countries exporting the luxury items to Colombia. Only a small group of educated elites, typically youthful, wanted to consume those items, as part of their drive to adapt European and North American lifestyles and values to Colombia. In the second half of the century, both access to and desire for imported goods increased, due in large part to the growing dominance of liberal ideologies that viewed countries such as Great Britain, France and the United States as ideal exemplars for the nascent Spanish American nations. Writing of Spanish American elites' push to develop what they saw as their backward-thinking, tradition-bound societies, Christopher Conway avers, "the drive to civilize was, in essence, the drive to modernize - to prod Spanish American societies onto the same road to perfectibility that European societies and the United States were supposedly traveling" (Conway 2015, 10). Latin Americans sought to modernize all aspects of their societies, from education to, as we see, such quotidian activities as eating. In his Reminiscencias de Santafé y Bogotá, José María Cordovez Moure wrote of the young men who traveled to Europe, "los que aprovechaban su tiempo traían al país conocimientos útiles y hábitos de cultura y buen gusto que fueron implantando lentamente" (1899). Their newfound knowledge and "good taste" prompted them to want to recreate in Colombia the practices they had experienced abroad. González Stephan comments, "La burguesía [...] en su compulsivo afán por ascender y colocarse, debía adquirir refinados modales y un saber decir como las formas de su blanqueamiento y occidentalización. [.... Las buenas maneras [...] representaban ahora un valor (y no una virtud) mercadeable, porque tanto la apariencia (limpieza, salud, vestuario) y saber decir eran un capital simbólico que podía colocar a cada individuo [...] en la jerarquía social más alta" (González Stephan 1999). This generation with its direct exposure to Europe and familiarity with European norms created new markets in Colombia for European wines and spirits, cuisines, and dining styles.

Immigration from Europe to Colombia was never massive in the way that it was in Argentina, Brazil or Uruguay; in 1851, for example, 1,527 foreigners were living in Colombia (García Estrada 2006, 25). By 1912 there were 9,068 foreignborn men and women resident in the country (García Estrada 2006,36 ). These immigrants lived all over the country, mostly concentrated in Bogotá and the provincial capitals, but their physical presence was not significant enough in and of itself to affect Colombians' attitudes, especially regarding food and dining. Nonetheless, immigrants both sought out familiar foods from their home countries and made those foods available to Colombians by opening stores and restaurants offering French, German, Italian and Spanish cuisine. For example, in Bogotá Paulina García and her Spanish husband opened a dessert shop selling "exquisitos postres santafereños, además de los marzos, los poinonos, las repollas cuyo nombre francés era choix, los éclairs o repollas alargadas, y las milhojas o millefeuilles de origen extranjero" (Restrepo 2009, 61-62). At the same time, the 1860 s and 1870 s saw a marked increase in imported goods and in the development of a middle class to consume such goods. The act of consumption allowed consumers to see themselves as leading the highly desirable lifestyle with which such imports were usually associated, and to demonstrate their cultural sophistication to their peers. Immigrants from Europe opened stores selling imported goods including French, Italian, Spanish and English food items, and they worked to popularize their wares and the lifestyle experiences associated with them. Food imports rose significantly. In 1858-59 the total cost of imported consumables (food, drinks, salt) was $\$ 190,416$ and by $1870-71$ that figure had climbed to $\$ 4,392,015$ (Martínez Carreño 1990, 70). Likewise, the expansion of the middle class meant that more people had disposable income to spend on items previously seen as luxurious extravagances. So Bogotans adopted French and British dining customs; lunch, not almuerzo, was popular, as was the habit of drinking tea; and menus were written and presented in French.

These changes in cultural norms and behaviors related to food included an increased number of restaurants catering to the middle and upper classes. Until mid-century, "la gente generalmente comía en la casa aunque existían algunos locales que vendían comida preparada, y las fondas donde ocasionalmente se iba a comer, a pesar de su desaseo y mal aspecto; la otra opción eran las chicherías que no superaban el ambiente de las anteriores" (Restrepo 2009, 132). With the rise of chefs, hotels and restaurants offering fine, not to mention refined, dining experiences that were marketed to the upper class and to the aspiring middle classes, Colombians' appetites for elegant meals served outside the home were whetted. As the circulation of discourses holding up the models of Europe and North America increased, middle-class and elite Colombians increasingly sought ways 
to demonstrate their modernity and worldliness. Dining in restaurants put their sophisticated lifestyles on public view: "Tomaban las clases altas del país un viso cosmopolita, aún sin haber viajado y más si ya lo habían hecho" (Martínez Carreño 1990, 76). Banquets moved from the supposedly private space of the home to the public space of the restaurant, which was also, significantly, a place where the presence of elite women was not visible. If in the home they might at least have been supposed to have a hand in designing the menu and overseeing the cook, now even that role vanished as men hosted banquests in restaurants rather than in their own dining rooms.

Elite restaurants featured European cuisine and advertised that fact as one of their chief selling points, as when the Gran Hotel y Restaurante de Bolívar in Cartagena ran the following advertisement on the front page of El Conservador on May 26, 1884: "Cocina francesa, española e italiana, y de lo mejor que ofrece este excelente mercado; Comedor y Restaurante con mesas separadas y dispuestas para una o varias personas; Cantina bien provista de toda clase de vinos y licores." El Conservador also reported in its October 10, 1883 issue on a political banquet: "El señor Gobernador del Estado obsequió el sábado a los miembros de la Asamblea Legislativa con un suntuoso banquete en el 'Restaurante Español.' Representadas allí las distintas agrupaciones políticas, reinó la más perfecta y cordial armonía." As the Liberals and Conservatives continued to struggle for power in the 1880 s, political accord between the two parties was increasingly elusive and, indeed, the Radical branch of the Liberal party launched an ill-fated revolt against Rafael Núñez's presidency in 1885. El Conservador's representation of this 1883 state banquet, which brought together the executive and legislative branches, sought to offer an anxious readership some assurance that warring factions could find common ground, at least in the neutral territory of the Restaurante Español.

Celebrations in honor of the centenary of the birth of Simón Bolívar two months earlier also united politicians, career public servants, journalists, and merchants. On July 23, 1883, Papel Periódico Ilustrado reported:

se celebró en el mismo Palacio de Gobierno del Estado, un suntuoso banquete a que asistieron el señor Presidente de la República y sus siete Secretarios, el Cuerpo diplomático y consular, y más de cien notabilidades del Gobierno, la prensa, el comercio, etc. Allí en medio de las luces, las flores, la música y las espumas de champaña, con la grata efusión de los hermanos reunidos para celebrar la fiesta del padre, el Libertador recibió la más satisfactoria manifestación, al unirse la mano del Ministro de España a la de los colombianos para saludar su memoria. (Papel Periódico 1883)
Rather than taking place in a restaurant, President José Eusebio Otalora hosted the banquet in the then-Presidential Palace, the Palacio de San Carlos. Both the president's official residence and the seat of the Colombian government, the palace was clearly marked as a public gathering space; the attendees at the July 23 banquet were not invited into the president's domestic space, but rather welcomed to a a governmental building. The Manual of Carreño even dictated the seating arrangements for this kind of diplomatic dinner:

Cuando en un banquete se hallen presentes varios Ministros de Estado, la preferencia en los puestos que han de ocupar en la mesa, será establecida por el rango que cada cual ocupe en el Gabinete: si se hallan presentes varios Ministrosextranjeros, la preferencia será igualmente establecida por el rango diplomático de cada cual [...]. Siendo el Jefe del Estado el que dé el banquete, es de etiqueta que posponga en la mesa sus Ministros a los Ministros extranjeros. (Carreño $1853,233)$

The event highlighted, as Papel Periódico Ilustrado took pains to indicate, international reconciliation and offered an opportunity for national representatives of all sectors to unite with the common purpose of honoring Bolívar's birthday. Relations between Spain and Colombia had taken a turn for the better with the 1881 signing of "Tratado de Paz y Amistad." Colombia was one of the last Spanish American nations to sign such a treaty with Spain (Núñez 2010, 134), and commemorating the improved relationship was important to those Colombians who saw it as consolidating their nation's status on the world stage. Papel Periódico Ilustrado's description of the Minister of Spain's participation in honoring Bolívar as being "la más satisfactoria manifestación" both highlights the importance of Spain's presence at the event and subtly points to the triumph over Spain that liberation signifies. Hence the journal carefully presents the banquet as functioning on multiple levels of communicative importance to be read and understood by the many readers who thus participate figuratively in the dinner despite not being there in person. In the same issue, the journal reported on a banquet held at the Jockey Club the following evening, July 24, 1883, likewise to celebrate the Bolivarian centenary. Founded in 1874, the Jockey Club was immediately successful among the elites of Bogotá and was a prestigious location for this dinner, hosted by the editors of the Correo Mercantil in honor of the Associated Press of Colombia. Perhaps because the editors and journalists of the Papel Periódico Ilustrado were professional colleagues of their hosts, their report calls this banquet "uno de los más brillantes de la fiesta del día," thanks in part to "el notable personal que concurría," made up of the Prensa Asociada's president, politicians including President Otalora, and "varios notables literatos" (1883). These events reverberated beyond those who attended due to the assiduous reporting in contemporary periodicals, which disseminated information about the importance and cultural meaning of 
the banquets to readers throughout the country. Specifically, these accounts used their descriptions of the banquets, which according to the reporters peacefully brought together opposing political factions and representatives of the intellectual, financial and political sectors of Colombian society, in order to advance an image of Colombia as a smoothly functioning, strife-free nation.

Throughout the century, banquets served several purposes. The occasion itself was usually advertised as bringing people together around a common issue or event and creating harmony and unity among the attendees; the unstated goal was often to communicate one political party's ability to control public space and manipulate social norms so as to exclude or marginalize the opposition. Banquets were also held in order to impress the guests, be they Colombian or international dignitaries, with the host's financial, social, and political power. As this essay shows, the intended outcomes of the events did not always become reality, given the very real political cleavages that wreaked havoc on Colombia's political processes. In all situations, nonetheless, newspaper accounts memorialized the banquet in specific and intentional ways, upholding the agenda of the event organizers or undermining it. Regardless of whether the banquet itself achieved the hosts' goals, the newspaper accounts created and disseminated versions of the events that allowed them, and their messages, to reach far more people than had attended the original meal in question. The often unspoken understanding of the social norms shaping the space and practices associated with banquets and those who attended them bound people together regardless of which side of the political divide they stood on. Journalists attached political and cultural meanings to the festivities they described and shaped their audience's views of political events and attitudes by activating their readers' implicit expectations of how meals functioned socially and what the attendees' roles were at such meals. Food and its consumption in public venues, then as now, was a vehicle to convey multiple messages that went far beyond the merely culinary.

\section{Works Cited}

Bauer, Arnold J. 2001. Goods, Power, History: Latin America’s Material Culture. New York: Cambridge University Press.

Carreño, Manuel Antonio. Manual de urbanidad y buenas maneras para uso de la juventud de ambos. New

York: D. Appleton and Company, 1857 [1853]. Accessed May 24, 2019. https://books.google.com/

books? $\mathrm{id}=1 \mathrm{jhcAAAAcAAJ} \&$ printsec $=$ frontcover $\& \mathrm{dq}=$ manuel + antonio + carreno $\&$ hl $=$ en\&sa $=$ X\&ved=0ahUKEwjr0uPq0r

LiAhWMAXwKHXTxC54Q6AEINTAB\#v=onepage\&q\&f=false

Chapman Quevedo, Willian Alfredo. 2013. "Formas de sociabilidad política en Popayán, 1832-1853”. Anuario de Historia Regional y de las Fronteras 18: 2: 321-353. Accessed May 24, 2019. https://revistas.uis.edu.co/index.php/anuariohistoria/ article/view/3872/5125

Conway, Christopher. 2015. Nineteenth-Century Spanish America: A Cultural History. Nashville: Vanderbilt University Press.

Cordovez Moure, José María. 1936. De la vida de antaño. Bogotá: Editorial Minerva. Accessed June 1, 2017. http://babel. banrepcultural.org/cdm/ref/collection/p17054coll10/id/3611

----. 1899. Reminiscencias de Santafé y Bogotá. Accessed August 9, 2018. http://www.ellibrototal.com/ ltotal/?t=1\&d=6312_6081

Cubillos Vergara, María Carolina. 2012. "El difícil tránsito hacia la modernidad: La prensa en Colombia.” Folios 27: 47-65.

Derrida, Jacques. 2000. Of Hospitality. Trans. Rachel Bowlby. Stanford, CA: Stanford University Press.

El Conservador, October 10, 1883 and May 26, 1884.

El Pasatiempo, September 8, 1852 and February 15, 1854.

Ferguson, Priscilla Parkhurst. 2014. Word of Mouth: What We Talk About When We Talk About Food. Berkeley: University of California Press. EBSCOhost.

García Estrada, Rodrigo de J. 2006. Los extranjeros en Colombia: su aporte a la construcción de la nación (1810-1920). Bogotá: Planeta. 
González Bernaldo de Quirós, Pilar. 2015. "Sociabilidad y regímenes de lo social en sociedades post-imperiales: Una aproximación histórica a partir del caso argentino durante el largo siglo XIX." Sociabilidades en la historia. Eds. Santiago Castillo and Montserrat Duch. Madrid: Asociación de Historia Social. 213-234. Accessed May 25, 2019. http:// historiapolitica.com/datos/biblioteca/sociabilidades_gonzalez\%20bernaldo.pdf

González Stephan, Beatriz. 1999. “Cuerpos de la nación: cartografías disciplinarias.” Anales - Instituto Ibero Americano. Nueva Época 2: 71-106.

---. 1994. “Modernización y disciplinamiento. La formación del ciudadano: del espacio público y privado.” Esplendores y miserias del siglo XIX: Cultura y sociedad en América Latina. Eds. Beatriz González Stephan, Javier Lasarte, Graciela Montaldo and María Julia Daroqui. Caracas: Monte Ávila. 431-455.

“Indignación pública". 1850. La Civilización, March 14, 1850.

Loaiza Cano, Gilberto. 2011. Sociabilidad, religión y política en la definición de la nación: Colombia, 1820-1886. Bogotá: Universidad Externado de Colombia.

López, Natalia. 2017. "Los orígenes de un best seller: publicación, circulación y recepción de la urbanidad de Carreño en América Latina". Historia 2:50 (July-December): 641-662. Accessed May 23, 2019. https://www.redalyc.org/ pdf $/ 334 / 33454021008$.pdf

Martínez Carreño, Aída. 1990. Mesa y cocina en el siglo XIX: Colombia. Bogotá: Ministerio de Cultura.

Núñez, Pilar Trinidad. 2010. "El proceso de las relaciones en el ordenamiento internacional entre Colombia y España como dos estados soberanos: una mirada desde España." Revista Electrónica Iberoamericana 4 (1): 116-143. Accessed August 14, 2018. https://www.urjc.es/ceib/revista-electronica-iberoamericana

Papel Periódico Ilustrado, July 24, 1883 and August 20, 1883.

Red Cultural del Banco de la República de Colombia. n.d. "Julio Arboleda Pombo". Accessed July 16, 2018. http://enciclopedia. banrepcultural.org/index.php?title=Julio_Arboleda_Pombo.

Restrepo, Cecilia M. 2009. La alimentación en la vida cotidiana del Colegio Mayor de Nuestra Señora del Rosario 1776-1900. Bogotá: Editorial Universidad del Rosario.

Rojas, Cristina. 2002. Civilization and Violence: Regimes of Representation in Nineteenth-Century Colombia. Minneapolis: University of Minnesota Press.

Torres Caicedo, José María. 1850. “Capítulos de carta”. El Día, March 30, 1850.

Tovar Pinzón, Hermes. 1994. "La manumisión de esclavos en Colombia, 1809-1851, aspectos sociales, económicos y políticos." Credencial Histórica 59 (November). http://www.banrepcultural.org/biblioteca-virtual/credencial-historia/numero-59/lamanumision-de-esclavos-en-colombia-1809-1851. Accessed July 16, 2018.

Uribe-Urán, Víctor M. 2003. “Sociabilidad política popular, abogados, guerra y bandidismo en Nueva Granada, 1830-1850: respuestas subalternas y reacciones elitistas." Historia y Sociedad 9: 89-116.

Valencia Llano, Antonio. n.d. "El general José Hilario López, un liberal civilista.” www. banrepcultural.org. Accessed July 16, 2018.

Vasco Bustos, Bernardo. 2011. Periodismo político: La prensa bogotana en el siglo XIX. Bogotá: Alcaldía Mayor de Bogotá. 